cap and chain, and for gnomon a gold pin surmounted by a delicately chased animal head, with jowelled eyes and $a$ ball in its mouth. 'This pin, when not in use, rested in a holo at the lower end of the tablet, and was in this position when the time-piece was found. On the faces of the tablet aro inscribed the names of the months, abbreviated and in pairs. It the top of each of the three columns is a hole for the pin when in uso, and below each holo two spots. Of theso the higher in each month, when the dial hangs frec, indicates noon and tho lower 9 a.m. and 3 p.m. marking the hours of the monks' services. Along the edges runs the inscription: Pax PossessoriSalus Factori. Tho dial has been tested for accuracy by Dr. A. H. Smith of University Collego, London. The grouping of the months in pairs according to their equivalent distances from the summer solstice is based, it is to bo presumed, on the table given by I3edo for measuring the shadow of a six-foot gnomon. Dr. Smith finds that owing to its small size, tho dial could only bo approximately accurate. It would, however, bo moro or less correct at noon in latitudo 5) $3^{\circ} \mathrm{N}$. at the middle of certain months, or early in others, while in the far north of England it would bo more or less accurate through tho summer months. At 9 a.m. and 3 p.m. it would bo moro or less accurato in late January, mid-February, mid-. Iarch, early April, carly May, lato July, mid-September, early October, early November and early December.

\section{Anglo-Saxon Ship Burial}

Ship bURials are of sufficient rarity, oven on the Continent, for the discovery of an Anglo-Saxon ship burial at Sutton Ifoo, near Ipswich (The Times, July 26, July 31) to be regarded as a memorable and, indeed, remarkable event. This is, in fuct, only the second of the kind to be found in Erigland, a previous discovery, though of a rather less impressive character, having been mado at Snape, two miles away. In the present instance, the vessel in which the interment had taken place was a rowing galley $82 \mathrm{ft}$. long. The quantity and character of the jewellery and other personal objects associated with the burial wero such as to justify tho assumption that a chief lay buried here. The personal relics were found collected together in tho centre of tho ship, and included a handsome gold buckle, clasps and fastenings of the garments, gold studs from a belt, and small plaques of gold bearing figures of human beings and unimals. The sword had been laid by the side of the body; but it has almost entirely perished, with the exception of the richly ornamented gold and jewelled pommel. The deceased had also been provided with money, tho remains of a purse being found beside some coins. Other articles found with the burial were iron pots and spearheads, and an object which has the appearance of a sceptre, having faces carved at either end. A metal cup may, it is thought, have contained some articles of symbolic significance. The grave is situated on the estate of Mrs. E. M. Pretty, and has been excavated by tho authorities of the Ipswich Museum, under the field direction of Mr. Guy Maynard, with the co-operation of H.M. Office of Works and the British Mluseum.

\section{Lightning Flashes and High Tension Mains}

Dunis: July there were many violent thunderstorms and much damage was dono to overhead electric mains and substations connected with them. The damage done to main stations was also sovere. On July 19, a violent thunderstorm cut off Valley Road Power Station at. Bradford from tho Grid and shut down all tho generating sets thero. For about an hour, mills, factories, trams and trolley-buses on many routes camo to a standstill; the traffic lights failed and there was no light anywhere for about an hour. A similar occurrence took place at the Brighton Power Houso at Southwick. In both cases the difficulties of the staff were increased as they wero engaged in changing over on the Grid supply from $6 \cdot 6$ kilovolt to 33 kilovolt. There was a heavy storm over Cumberland and the overhead transmission was struck. This affected the supply to more than 30,000 houses in Cockermouth, Maryport, Aspatria and Wigton as well as part of Workington, the lights being out from 3.15 p.m. to 8.30 p.m. On July 19 , at 8 p.m., the B.I3.C. National Transmitter at Droitwich was struck by lightning and put out of action. The flashes striking the 700-ft. masts of the Radio Station wero extremely violent. Flames shot from the cage of aerial wires slung between tho masts. In somo places transformers or switchgear wero damaged and three fires broko out, destroying substation roofs or walls. Since thunderstorms aro less frequent in Great Britain than in South Africa and other parts of the world it might be useful to study the effects of modern lightning protectors in protecting poles, steel towers, overhead mains, etc.. in places whero thunderstorms aro frequent and violent. Also when designing new grids or extensions of old ones to get estimates of the relativo costs of overhead mains and of underground mains. A decision could then bo arrived at as to which is tho better method of transmitting high-tension electric power.

\section{Empire Broadcasts on Scientific Topics}

TuE I3ritish I3roadcasting Corporation has instituted a short series of quarter-hour broadcasts to the Empire on recent advances in science. The first talk of the series was given at 11.15 p.m. on July 31 by Yrof. Allan Ferguson, one of the general secretaries of the British Association. Prof. Ferguson, after giving $a$ simple picture of the structure of the atom, and the results to be expected from atomic bombardment, described briefly tho dovelopment of the cyclotron, recent experiments on nuclear disintegration, including the uranium-fission experiments, and the production of 'labelled' particles. Succeding talks will bo given by Wing-Commander Cave-Browne-Cnvo on mechanical engineering (August 7), by Dr. S. J. F. Philpott on psychology (August 14) and by Prof. F.A. E. Crew on biology (August 21).

\section{League of Nations}

"The League from Year to Year (1938)", which has recently been issued by the Information Section of the Secretariat of the League of Nations, contains the usual concise account of the year's activities in 
sufficient detail to facilitate careful study of the political, legal and technical work of the various organs of the League of Nations. (Geneva: Iseague of Nations; London: Georgo Allen and Unwin, Ltd., 1939. Pp. 214. 1s.). Of special interest to scientific workers are the chapters on intellectual co-operation, the health organization, the communications and transit organization and those on the Furopean conference on rural life and technical collaboration with China. A chapter dealing with refugees is included as well as one on mandates. The detailed chronological tablo of the principal events in the Iscague's sphero of activity during the year, giving the dates of the meetings of the different organs of tho Leaguo and of their principal decisions, as well as of world political ovents affecting the I.eaguo's work introduced last year for the first time is again a feature of tho now edition.

\section{The Colonial Problem}

THe proposals of the I,abour and Peace movements for dealing with the colonial question aro examined in a pamphlet "Now Tendencies in Colonial Policy" issued by the Pacifist Research Bureau (New Tendencies in Colonial Policy. With an Introduction by Leonard Bames. Pp. 16. Iondon : Pacifist Research Bureau, 1939. 2d.). It is argued that there are only two alternatives: an extended and re. arranged imperialism with now rival imperialisms of greater cquality and an ultimate clash between them; or tho removal of existing imperialisms and their substitution by a great conception of civiliza. tion's responsibility for tho so-called uncivilized, with an equally great concoption of world economic organization. The necessity of conforming to tho wishes, or, at least, obtaining the consent of the native peoples in all matters affecting their welfare is also emplasized, including tho application of this principlo not only to the mandated territories but also in other colonial questions. The problem is further discussed in another pamphlet issued by the Bureau, "War and the Colonies" (War and the Colonies: a Policy for Socialists and Pacifists. PP. 16. Iondon : Pacifist Research Bureau, 1939. 2d.), in which proposals for a world conference to effect tho liquidation of imperialism are briefly outlined.

\section{Language in Science}

THE general considerations of linguistics which throw light upon the procedure of science are dis. cussed by $L$. Bloomfield in the fourth number of volume one of the "International Encyclopedia of Unified Science" (Linguistic Aspects of Science. By Leonard Bloomfield. Pp. viii +60 . (Chicago : University of Chicago Press; London : Cambridge University Press, 1939.) 5s. net.). If language is taken into account, science can bo distinguished from other phases of human activity by agreeing that science shall deal only with ovents that aro accessiblo in their timo and place to any and all observers or only with events that aro placed in co-ordinates of timo and space, or that science shall employ only such initial statements and pre. dictions as lead to definite handling operations or only terms such as aro derivablo by strict definition from a set of everyday terms concerning physical happenings.

IT is the task of science to provide a system of responses which are independent of the habits of any person or community, but Mr. Bloom. field points out how far short wo aro of accurate definition in regard to meanings which aro involved in the habits of communities and individuals, since the relevant branches of science are quite undeveloped. Discussing the development of scientific language, ho distinguishes between the informal and formal scientific discourse, and emphasizes the importance of defining exactly the meaning of technical terms and limiting their use within the agreements upon which they are based. When meanings of the outside world are admitted, error may be incurred and certainty is lost. With regard to the place of linguistics in the schemo of science Mr. Bloomfield places it between biology and ethnology, sociology and psychology. It stands between physical and cultural anthropology. It is closely rolated to logic, since it observes how people conduct a certain typo of discourse. The critique and theory of scientific speech is tho task of logic. Mathematics, howover, is a science only so long as wo believe that the mathematician is not creating speech-forms and discourses (which is a slill, craft, or art) but exploring an unknown realm of concepts or ideas.

\section{Library Services in the United States}

UNDER tho title "Professional Library Iiducation" the Office of Education, United States Department of the Interior, has issued a bullotin by Nora $E$. Boust (Bull. No. 23; 1937) describing tho present position of library sorvices in the United States and indicating tho possibilities it offers as a carcer, and tho qualifications required for the various ficlds of service. Much that is said of the different types of library such as the public library, the school, the university or the special library is truo generally, and if duo allowance is mado for the different conditions and details in tho United States, this pamphlet gives a reasonably sound guido to tho possibilities in Great Britain also, oven if somo directions have beon much moro doveloped in the United States. Details regarding training for librarianship, like the figures showing tho present status of tho profession, relato solely to tho United States and at tention is directed to a marked growth in the number of librarians in the last threo decades, particularly in comparison with tho number of practitioners in other professions. Somo reasons for success and fuilure in library work which are set forth in conclusion aro of general validity.

\section{The Society of Applied Biologists}

PrIor to the year 1904 thero was no sciontific society or journal in the United Kingdom devoted to applied biology. There was, moreover, little opportunity or encouragement for rosearch in this field, and the work of the universitios and other 